\title{
Pomegranate Juice and Warfarin Interaction: A Case Report
}

\author{
Nar Suyu ve Varfarin Etkileşimi: Olgu Sunumu
}

\author{
Gülhan Kurtoğlu Çelik', Gül Pamukçu Günaydın', Nurettin Özgür Doğan'1, Murat Mahmut Dellül'1, Havva Şahin Kavaklı² \\ 'Department of Emergency Medicine, Ankara Atatürk Training and Research Hospital, Ankara, Turkey \\ 2Department of Emergency Medicine, Yıldırım Beyazıt University, Ankara, Turkey
}

\section{ABSTRACT}

Introduction: Warfarin is a frequently used anticoagulation drug that is metabolized by cytochrome P450 enzymes. There are publications that show that pomegranate juice inhibits the activity of these enzymes, but there are only a few case reports about the possible interaction of pomegranate juice with warfarin. A patient with high INR after simultaneous use of warfarin and pomegranate juice is presented.

Case Report: A 54-year-old male patient who recently started warfarin treatment $1 \times 5 \mathrm{mg} /$ day presented to the emergency department for INR control on the sixth day of treatment. The patient had no complaints, and his physical examination revealed no pathological findings. His INR was 12.9 (0.8-1.2). In his medical history, no food or drug interactions were detected, except that he has been drinking pomegranate juice $200 \mathrm{ml} /$ day. Pomegranate juice and warfarin were interrupted, and an INR fall was observed. Then, the patient was started on 1x5 mg warfarin again. INR measurements were in the therapeutic range.

Conclusion: When taking the medical history of patients with warfarin use, all drug and food consumption that may affect the metabolism of warfarin should be investigated. It is essential to inform these patients about possible interactions.

Keywords: Emergency medicine, warfarin, pomegranate

Received: 07.03.2013 Accepted: 08.07.2013

\section{ÖZET}

Giriş: Varfarin antikoagulasyon amacı ile sık olarak kullanılan bir ilaç olup sitokrom P450 enzimleri ile metabolize edilir ve bu enzimlerin aktivitelerini azaltan çeşitli ilaç veya besinler varfarinin etkisini arttırabilir. Literatürde nar suyunun sitokrom P450 enzimlerinin aktivitesini inhibe ettiğine dair yayınlar vardır ancak nar suyu varfarin olası etkileşimini bildiren sadece birkaç olgu sunumu mevcuttur. Acil servise nar suyu ve varfarin'in eşzamanlı kullanımı sonrası INR yüksekliği ile başvuran olgunun sunulması amaçlandı.

Olgu Sunumu: 54 yaşında erkek hasta acil servise atriyal fibrilasyon tedavisi için yeni başlanan günde $1 \times 5 \mathrm{mg}$ varfarin tedavisinin 6. gününde INR kontrolü yaptırmak amacı ile başvurdu. Herhangi bir yakınması olmayan hastanın yapılan fizik incelemesinde patolojik bulgu tespit edilmedi. Laboratuvar tetkiklerinde INR: 12,9 $(0.8-1,2)$ olarak saptandı. Öykü derinleştirildiğinde hastanın hergün yaklaşık $200 \mathrm{ml}$ nar suyu içtiği ve varfarin ile etkileşimi bilinen başka bir ilaç ya da gıda alımı olmadığı öğrenildi. Nar suyu ve varfarin birlikte kesildi, INR düşüşü gözlendi, daha sonra varfarin tekrar 1×5mg olarak başlandı ve hastanın kontrollerinde INR terapötik aralıkta kaldı. Herhangi bir komplikasyon gelişmedi.

Sonuç: Varfarin kullanımı olan hastalarda ilacın metabolizmasını etkileyebilecek tüm ilaç, gıda ve meyve suyu tüketimi gibi bilgilerin öyküde sorulması ve hastaların bu konuda bilgilendirilmesi çok önemlidir.

Anahtar Kelimeler: Acil tıp, varfarin, nar

Geliş Tarihi: 07.03.2013 Kabul Tarihi: 08.07.2013

\section{Giriş}

Günümüzde varfarin çeşitli endikasyonlarda antikoagülasyon amacı ile kullanılmakta olup, pek çok ilaç ve yiyeceğin varfarinle birlikte alındığı durumlarda varfarin'in etkisini arttırıp, azaltabileceği bilinmektedir. Varfarin aşıı dozuna bağlı komplikasyonlarla acil serviste sıkça karşılaşılmaktadır.

Punica granatum olarak da bilinen nar, bütün dünyada yaygın olarak tüketilmekte ve halk tıbbında pekçok hastalığı tedavi amacı ile kullanılmaktadır (1). Nar suyu ise son zamanlarda giderek yaygınlaşan bir içecek olup, C vitamini, B vitamini, polifenol (ella- 
gitannin ve flavonoidler) açısından zengin bir meyve suyudur. Son yıllarda yapılan bazı çalışmalar nar suyunun anti-oksidan, antiaterojenik, antihipertansif, antiinflamatuvar, antiinfektif, kardiyoprotektif, antiagregan, immunmodulatuvar, antikanser, kondroprotektif özelliklerinin olabileceğini göstermekte ve bu konudaki literatür bilgisi genişledikçe nar suyunun popülaritesi ve içimi de giderek artmaktadır. Tüketiminin artması ile birlikte nar suyu ilaç etkileşimi meydana gelme olasıığı da artmıştır.

Bu yazıda varfarinin nar suyu ile birlikte içimine bağlı ilacın etkisinde artma meydana gelen bir olgunun sunulması amaçlandı.

\section{Olgu Sunumu}

54 yaşında erkek hasta acil servise rutin INR kontrolü sebebi ile başvurdu. Öyküsünde 2 ay önce hastaya ST elevasyonu olmayan miyokard enfarktüsü nedeniyle perkutan koroner girişim yapılarak koroner bypass cerrahisi kararı alınmış olduğu ve hastanın operasyon için verilen randevu gününü beklediği öğrenildi. Hastaya acil servise başvurusundan 1 hafta önce atriyal fibrilasyon sebebi ile varfarin tedavisi başlanmış. Hasta başvurusundan önceki 5 gün boyunca her gün varfarin 1 X5mg dozunda kullanmış ve INR kontrolü ve varfarin dozu ayarlanması için acil servisimize başvurdu. Hastanın öyküsünde vücudunun herhangi bir yerinden kanama (idrarda, gaitada kan dahil) veya cilt bulgusu olmadığı öğrenildi. Yapılan fizik incelemesinde genel durumu iyi, vital bulguları stabil, bilinci açıktı, sistemik muayene ve nörolojik muayenesi normaldi, patolojik muayene bulgusu yoktu, herhangi bir kanama odağı tespit edilmedi, ekimoz, peteşi, purpura saptanmadı. Hastanın yapılan tetkiklerinde APTT: 44,5 sn (22-38), PT:120,2 sn (10,7-15,2) INR:12,9 (0,8-1,2) olarak saptandı. Hastanın öyküsü varfarin metabolizmasını etkileyecek ilaçlar ve besinler açısından derinleştirildiğinde, hastanın televizyonda duyduğu kalp koruyucu etkilerinden faydalanmak amacı ile son 1 aydır her gün 1 bardak (yaklaşık 200mL) nar suyu içtiği öğrenildi. Aktif kanaması olmayan hastada varfarin tedavisi ve nar suyu kesildi, hastaya acil durumlar hakkında bilgi verildi ve 2 gün sonra kontrole gelmek üzere hasta taburcu edildi. Hastanın 2 gün sonraki kontrolünde APTT: 37,6 sn (22-38), PT:34,8 sn (10,7-15,2) INR:3,1 (0,8-1,2) olarak saptandı. Hastaya her gün varfarin 1x5 mg kullanması ve nar suyu içmemesi önerildi. Hasta 1 hafta sonra kontrole geldiğinde APTT: 30,5 sn (2238), PT:31,7 sn (10,7-15,2) INR:2,78 (0.8-1,2) saptandı, ve 3 ay boyunca yapılan aylık takiplerinde INR düzeyi 2,5-3 arasında stabil seyretti.

\section{Tartışma}

Literatürde nar suyu ile varfarinin olası etkileşimini gösteren birkaç olgu sunumu mevcuttur. Sitokrom P450 enzimleri pek çok ilacın metabolizmasında yer alır. Bu sınıfta 50'den fazla enzim vardır fakat bunların 6 tanesi ilaçların \%90'ını metabolize eder. Sitokrom P 450 enzimlerinin aktivitesi çeşitli ilaçlar veya besinlerden etkilenebilir (2). Nar suyunun sitokrom P450 enzimlerinden CYP3A ve CYP2C9'u inhibe ettiği bilinmektedir $(3,4)$. Varfarin metabolizması ve varfarinle gıda veya ilaçların etkileşimi CYP1A2, CYP3A4, CYP2C9 enzimleri üzerinden olur (5). Laboratuvar çalışmaları nar suyunun, varfarin metabolizmasında da yer alan sitokrom P450 enzimini inhibe ettiğini göstermiştir ve bu durum varfarin ile nar suyu arasındaki potansiyel etkileşimi açıklamaktadır (3). Varfarinin antikoagülan etkinliği, özellik- le S-varfarinin CYP2C9 ile olan metabolizması bozulduğunda değişir, bu enzim çoğunlukla intestinal epitelde bulunur ve son çalışmalar nar suyunun bu enzim için potent bir inhibitör olduğunu göstermektedir (5). Diğer bazı çalışmalarda nar suyunun intestinal CYP3A enzimini inhibe ettiği $(3,4)$ böylece varfarin absorbsiyonunu artırabileceği gösterilmiştir (4).

Literatürde diğer meyve suları ve varfarin etkileşimleri bildirilmiştir ve varfarinin yaptığı antikoagülasyonun greyfurt suyunun neden olduğu CYP3A inhibisyonu sayesinde arttığı iyi tanımlanmıştır (6). Üç vakada da varfarin ile yaban mersini olası etkileşim bildirilmiştir. Bu etkileşimin de sitokrom P450 enzimlerine bağlı olduğu düşünülmektedir (7).

Gıda ve varfarin ile ilgili önceki bildirimler gibi bu olgu da artmış varfarin biyoaktivitesi ile nar suyu tüketimi arasındaki ilişki için kesin kanıt niteliği taşımaz. Hastamızda varfarin ve nar suyunun birlikte alımı ile birlikte hızı bir INR yüksekliği meydana gelmişti, nar suyu ve varfarin alımı kesildikten sonra INR terapötik seviyelere indi ve aynı dozda varfarin nar suyu olmadan tekrar başlandığında her ikisinin birlikte alındığı durumda olduğu gibi bir INR yüksekliği gözlenmedi, INR terapötik düzeylerde seyretti. Bu sebeple hastadaki varfarinin etkisini arttıran faktörün muhtemelen nar suyu olduğu düşünüldü.

\section{Sonuç}

Bu yazıda nar suyu tüketimi ile varfarin'in birlikte kullanımına bağlı varfarin'in antikoagulan etkisinde artma görülen bir olgu sunuldu. Varfarin kullanımı olan hastalarda ilacın metabolizmasını etkileyebilecek tüm ilaç, gıda ve meyve suyu tüketimi gibi bilgilerin öyküde sorulması ve hastaların bu konuda bilgilendirilmesi çok önemlidir. Varfarin kullanımı ile birlikte beklenmeyen bir şekilde INR yüksekliği meydana gelen hastalarda bu etkenler özellikle sorgulanmalıdır.

Hasta Onamı: Hasta kimlik bilgileri gizli tutulduğundan ve herhangi bir girişim yapılmadığından hasta onamı alınmadı.

Hakem değerlendirmesi: Dış bağımsız.

Yazar Katkıları: Fikir - G.K.Ç., G.P.G., N.Ö.D., M.M.D., H.Ş.K.; Tasarım G.K.C.., G.P.G., N.Ö.D., M.M.D., H.Ş.K.; Denetleme - G.K.C.., G.P.G., N.Ö.D., M.M.D., H.S..K.; Malzemeler - G.K.Ç., G.P.G., N.Ö.D., M.M.D., H.Ş.K.; Veri toplanması ve/veya işlemesi - G.K.Ç., G.P.G., N.Ö.D., M.M.D., H.Ş.K.; Analiz ve/veya yorum - G.K.Ç., G.P.G., N.Ö.D., M.M.D., H.Ş.K.; Literatür taraması - G.K.Ç., G.P.G., N.Ö.D., M.M.D., H.Ş.K.; Yazıyı yazan - G.K.Ç., G.P.G., N.Ö.D., M.M.D., H.Ş.K.; Eleştirel İnceleme - G.K.Ç., G.P.G., N.Ö.D., M.M.D., H.Ş.K.

Çıkar Çatışması: Yazarlar herhangi bir çıkar çatışması bildirmemişlerdir.

Finansal Destek: Yazarlar bu çalışma için finansal destek almadıkları$\mathrm{n}$ beyan etmişlerdir.

Informed consent: Informed consent was not received by the patient.

Peer review: Externally peer-reviewed. 
Author contributions: Concept - G.K.Ç., G.P.G., N.Ö.D., M.M.D., H.Ş.K.; Design - G.K.Ç., G.P.G., N.Ö.D., M.M.D., H.Ş.K.; Supervision - G.K.Ç., G.P.G., N.Ö.D., M.M.D., H.Ş.K.; Materials - G.K.C.., G.P.G., N.Ö.D., M.M.D., H.Ş.K.; Data Collection and/or Processing - G.K.Ç., G.P.G., N.Ö.D., M.M.D., H.S.K.; Analysis and/or Interpretation - G.K.Ç., G.P.G., N.Ö.D., M.M.D., H.Ş.K.; Literature Review - G.K.Ç., G.P.G., N.Ö.D., M.M.D., H.Ş.K.; Writer - G.K.Ç., G.P.G., N.Ö.D., M.M.D., H.Ş.K.; Critical Review - G.K.Ç., G.P.G., N.Ö.D., M.M.D., H.Ş.K.

Conflict of Interest: The authors declared no conflict of interest.

Financial Disclosure: The authors declared that this study has received no financial support.

\section{Kaynaklar}

1. Langley P. Why a pomegranate? BMJ 2000; 321: 1153-4. [CrossRef]
2. Lynch T, Price A. The effect of cytochrome P450 metabolism on drug response, interactions, and adverse effects. Am Fam Physician 2007; 76: 391-6.

3. Nagata M, Hidaka M, Sekiya H, Kawano Y, Yamasaki K, Okumura M, et al. Effects of pomegranate juice on human cytochrome P450 2C9 and tolbutamide pharmacokinetics in rats. Drug Metab Dispos 2007; 35: 302-5. [CrossRef]

4. Hidaka M, Okumura M, Fujita K, Ogikubo T, Yamasaki K, Iwakiri T, et al. Effects of pomegranate juice on human cytochrome p450 3A (CYP3A) and carbamazepine pharmacokinetics in rats. Drug Metab Disposition 2005; 33: 644-8. [CrossRef]

5. Kaminsky LS, Zhang ZY. Human P450 metabolism of warfarin. Pharmacol Ther 1997; 73: 67-74. [CrossRef]

6. Paine MF, Criss AB, Watkins PB. Two major grapefruit juice components differ in intestinal CYP3A4 inhibition kinetic and binding properties. Drug Metab Dispos 2004; 32: 1146-53. [CrossRef]

7. Suvarna R, Pirmohamed M, Henderson L. Drug point - Possible interaction between warfarin and cranberry juice. BMJ 2003; 327: 1454. [CrossRef] 